\title{
ĐÁNH GIÁ KẾT QUẢ CHẨN ĐOÁN DI CĂN HACH Ở BỆNH NHÂN UNG THƯ PHỔI KHÔNG TẾ BÀO NHỎ ĐƯợC PHẪU THUẬT NộI SOI ĐIỀU TRI TẠI BỆNH VIỆN QUÂN Y 103
}

\author{
Vũ Anh Hải*, Lê Việt Anh*, Nguyễn Văn Nam*
}

\section{TÓM TẮT}

Mục tiêu: Nhận xét kết quả vét hạch ở bệnh nhân ung thư phổi không tế bào nhỏ bằng phẫu thuật nội soi và đánh giá vai trò chup cắt lớp vi tính lồng ngực và $\mathrm{PET} / \mathrm{CT}$ trong chẩn đoán hạch di căn. Đối tượng và phương pháp: Nghiên cứu mô tả trên 80 bệnh nhân ung thư phổi không tế bào nhỏ được cắt thùy phổi vét hạch bằng phẫu thuật nội soi. Kết quả: Tỷ lệ nam/nữ là 4,7/1, tuổi trung bình là $55,9 \pm 8,9$. Típ mổ bệnh chiếm chủ yếu là biểu mô tuyến $(95 \%)$, tế bào vảy $5 \%$. Giai đoan TNM trước mổ lần lượt là: IA $(40 \%)$, IB (15\%), IIA $(17,5 \%)$, IIB $(17,5 \%)$ và IIIA $(10 \%)$. Thùy phổi được cắt chủ yếu là thùy trên (31,2\% bên phải và $23,8 \%$ bên trái). Số trạm hạch N1 và $\mathrm{N} 2$ trung bình vét được trong mổ lần lượt là $1,8 \pm 0,8$ và $1,8 \pm 0,7$. Độ nhạy, độ đặc hiệu của CT trong chẩn đoán di căn hach N1 là $50,0 \%, 83,8 \%$; N2 là $62,5 \%, 86,1 \%$. Kết quả tương ứng của $\mathrm{PET} / \mathrm{CT}$ với hach $\mathrm{N} 1$ là 97,$7 ; 83,3$ và $\mathrm{N} 2$ là $97,5 \%$ và $83,3 \%$. Kết luận: Vét hạch bằng phẫu thuật nội soi khả thi, hiệu quả. Áp dụng $\mathrm{PET} / \mathrm{CT}$ trong chẩn đoán di căn hạch trước mổ đạt hiệu quả cao.

Tư khóa: Phẫu thuật nội soi lồng ngực, ung thư phổi, vét hạch.

\section{SUMMARY}

COMMENT ON THE LYMPHO NODE METASTASIS DIAGNOSIS IN NON-SMALL CELL LUNG CANCER PATIENTS WHO HAD TREATED BY VIDEO-ASISTED-THORACOSCOPIC

\section{SURGERY AT MILITARY HOSPITAL 103}

Objectives: Evaluate the results of lymph node harvest for $\mathrm{N}$ stage determination on non-small cell lung cancer (NCLC) patients by video-assistedthoracoscopic surgery (VATS). Calculate the sensitivity, specificity of computed tomography (CT) and PET/CT for lymph node metastasis diagnosis. Subjects and methods: A descriptive study on 80 non-small cell lung cancer patients who had been lobectomy and lymph node harvest by VATS. Results: The male/female ratio was $4.7 / 1$, the average of age was $55.9 \pm 8.9$. The type of histology consists mainly of adenocarcinoma $(95 \%)$, squamous cell was $5 \%$. The preoperative TNM stage consist of IA $(40 \%)$, IB $(15 \%)$, IIA $(17.5 \%)$, IIB $(17.5 \%)$ and IIIA (10\%). Distribution of lobectomy was mainly the upper lobe $(31.2 \%$ on the right and $23.8 \%$ on the

*Bênh viên 103, Hoc viện Quân Y

Chịu trách nhiệm chính: Vũ Anh Hải

Email: vuanhhai.ncs@gmail.com

Ngày nhận bài: 30/12/2021

Ngày phản biên khoa họ: $26 / 1 / 2021$

Ngày duyệt bài: 25/2/2021 left). The average station number of $\mathrm{N} 1$ and $\mathrm{N} 2$ lymph nodes removed was $1.8 \pm 0.8$ and $1.8 \pm 0.7$, respectively. The sensitivity (Se) and specificity (Sp) of $\mathrm{CT}$ in the diagnosis of $\mathrm{N} 1$ lymph node metastasis were $50.0 \%$ and $83.8 \%$, N2 were $62,5 \%$ and $86,1 \%$. The results was better by $\mathrm{PET} / \mathrm{CT}$ : $\mathrm{Se}=97.7 \%, \mathrm{Sp}=83.3 \%$ for $\mathrm{N} 1$ and $\mathrm{Se}=97,5 \%, \mathrm{Sp}=83,3 \%$ for N2. Conclusion: Lympho node harvest by VATS was feasible and effective. Application of CT and PET/CT in diagnosis of lymph node metastasis had good results.

Keywords: Video-Assisted-Thoracoscopic surgery, non-small cell lung cancer.

\section{I. ĐẶT VẤN ĐỀ}

Phẫu thuất nội soi (PTNS) lồng ngực điêuu trị ung thư phổi không tế bào nhỏ (UTPKTBN) lần đâu tiên được thực hiện bởi Rovario $G$ vào năm 1991. Hiện nay, phương pháp phẫu thuật này được ứng dụng ngày càng rộng rãi, với nhiều ưu điểm so với phẫu thuật mở ngực truyền thống như giảm đau, giảm tỷ lệ biến chứng sau mổ, rút ngắn thời gian nằm viện...

Chẩn đoán di căn hạch có ý nghĩa quan trọng trong chẩn đoán giai đoạn UTPKTBN, làm cơ sở để chỉ định các phương pháp điều trị và tiên lượng cho bệnh nhân UTPKTBN. Hiện nay, chụp cắt lớp vi tính (CLVT) và PET/CT được áp dụng phổ biến để chẩn đoán di căn hạch trước mổ, trong khi, kết quả mô học các hạch vét được trong mổ đóng vai trò là tiêu chuẩn vàng trong chẩn đoán di căn hạch. Nhiều nghiên cứu cho thấy, vét hạch bằng PTNS hiệu quả, kết quả tương đương mổ mở [2].

Chúng tôi thực hiện nghiên cứu nhằm nhận xét kết quả vét hạch ở BN UTPKTBN bằng PTNS và đánh giá vai trò chụp cắt CLVT lồng ngực và PET/CT trong chẩn đoán hạch di căn.

\section{II. ĐỐI TƯỢNG VÀ PHƯƠNG PHÁP NGHIÊN CỨU}

2.1. Đối tượng. Nghiên cứu mô tả, hồi và tiến cứu trên 80 bệnh nhân (BN) được chẩn đoán UTPKTBN được phẫu thuâtt tại Khoa phẫu thuật lồng ngực bệnh viện Quân Y 103, giai đoạn 05/2015 - 6/2020.

\section{Tiêu chuân lựa chọn:}

- BN được chẩn đoán xác định là UTPKTBN (theo kết quả giải phẫu bệnh sau mổ).

- Được PTNS cắt thùy phổi và vét hạch.

- Hồ sơ bệnh án đây đủ các chỉ số cân cho nghiên cứu. 

cứu.

2.2. Phương pháp. Nghiên cứu mô tả, tiến

Số liệu được thu thập theo mẫu hồ sơ nghiên cứu thống nhất và xử lý bằng phần mềm thống kê SPSS 20.0.

2.3. Quy trình phẫu thuật cắt thùy phổi, vét hach

- Chúng tôi thực hiên PTNS lồng ngực cắt thùy phổi với 3 đường vào: 2 troca (KLS VII/VIII đường nách trước/giữa và KLS V/VI đường nách sau/ dưới mỏm xương bả) và 1 đường mở ngực nhỏ (4 - $6 \mathrm{~cm}$ tại KLS IV/V đường trước bên/ giữa tùy theo vị trí thùy phổi)

- Vét hạch: Thăm dò các trạm hạch ở mỗi bên lồng ngực theo hướng dẫn của Hội phẫu thuật ung thư Hoa Kỳ (bên phải gồm các vị trí 2,4; bên trái 5,6; Các vị trí 7,8,9,10,11,12 được thăm dò như nhau ở cả 2 bên phổi) [5]. Tại các vị trí thấy hạch, thực hiện vét triệt để.

\subsection{Các chỉ tiêu nghiên cứu}

- Chỉ tiêu về đặc điểm nhóm nghiên cứu: Tuổi; giới tính; vị trí u; kích thước u; giai đoạn TNM

- Chỉ tiêu vét hạch gồm: vị trí vét được hạch, vị trí hach có di căn (theo kết quả mô bệnh sau phẫu thuật).

- Đánh giá kết quả CLVT, PET/CT trong chẩn đoán di căn hạch:

+ Lấy điểm cắt kích thước hạch là $10 \mathrm{~mm}$ trên CLVT, nếu lớn hơn $10 \mathrm{~mm}$ được chẩn đoán di căn hạch.

+ Chẩn đoán di căn hạch trên PET/CT: lấy giá trị SUV max là 2.5 làm điểm cắt. (Iớn hơn 2.5 chẩn đoán là di căn).

\section{KẾT QUẢ NGHIÊN CỨU}

\section{1. Đặc điểm bệnh nhân}

Bảng 1. Đăc điểm bệnh nhân trước mô

\begin{tabular}{|c|c|}
\hline Chỉ số & Giá trị \\
\hline Tuối & $55,9 \pm 8,9(38-77)$ \\
\hline Giới(nam/nữ) & $66 / 14=4,7$ \\
\hline \multicolumn{2}{|c|}{ Vị trí u trên CT } \\
\hline Thùy trên phải & $25(31,2 \%)$ \\
\hline Thùy giữa phải & $07(8,7 \%)$ \\
\hline Thùy dưới phải & $15(18,8 \%)$ \\
\hline Thùy trên trái & $19(23,8 \%)$ \\
\hline Thùy dưới trái & $14(17,5 \%)$ \\
\hline \multicolumn{2}{|c|}{ Kích thước u } \\
\hline$\leq 1 \mathrm{~cm}$ & $06(7,5 \%)$ \\
\hline$>1-2 \mathrm{~cm}$ & $22(27,5 \%)$ \\
\hline$>2-3 \mathrm{~cm}$ & $20(25,0 \%)$ \\
\hline$>3-5 \mathrm{~cm}$ & $22(27,5 \%)$ \\
\hline$>5 \mathrm{~cm}$ & $10(2,5 \%)$ \\
\hline Trung bình(cm) & $3,0 \pm 1,6(1-6,5)$ \\
\hline \multicolumn{2}{|c|}{ Giai đoạn TNM trước mố } \\
\hline \multicolumn{2}{|c|}{}
\end{tabular}

\begin{tabular}{|c|c|}
\hline IA / IB & $32(40,0 \%) / 12(15,0 \%)$ \\
IIA/IIB & $14(17,5 \%) / 14(17,5 \%)$ \\
\hline IIIA & $08(10,0 \%)$ \\
\hline
\end{tabular}

3.2. Kết quả vét hach bằng phầu thuật nội soi và xác định di căn hạch sau mổ

Bảng 2. Số trạm hạch được vét trong mô trên môt bênh nhân

\begin{tabular}{|c|c|c|}
\hline Số trạm hạch & Trung bình & NN - LN \\
\hline N1 & $1,8 \pm 0,8$ & $1-4$ \\
\hline N2 & $1,8 \pm 0,7$ & $1-3$ \\
\hline
\end{tabular}

Bảng 3. Di căn ung thư vào trạm hạch N1

\begin{tabular}{|c|c|c|c|c|}
\hline \multirow{2}{*}{$\begin{array}{c}\text { Số trạm hạch N1 } \\
\text { được vét trong } \\
\text { mổ (vị trí) }\end{array}$} & \multirow{2}{*}{$\begin{array}{l}\text { Số } \\
\text { bệnh } \\
\text { nhân }\end{array}$} & \multicolumn{3}{|c|}{$\begin{array}{c}\text { Số tram hạch N1 có } \\
\text { dí căn (vị trí) }\end{array}$} \\
\hline & & 0 & 1 & 2 \\
\hline 1 & 36 & 36 & 0 & 0 \\
\hline 2 & 28 & 26 & 2 & 0 \\
\hline 3 & 14 & 10 & 0 & 4 \\
\hline 4 & 2 & 2 & 0 & 0 \\
\hline Tống & 80 & 74 & 2 & 4 \\
\hline
\end{tabular}

Bảng 4. Di căn ung thư vào tram hạch N2

\begin{tabular}{|c|c|c|c|c|}
\hline \multirow{2}{*}{$\begin{array}{c}\text { Số trạm hạch N2 } \\
\text { được vét trong } \\
\text { mổ (vị trí) }\end{array}$} & \multirow{2}{*}{$\begin{array}{l}\text { Số } \\
\text { bệnh } \\
\text { nhân }\end{array}$} & \multicolumn{3}{|c|}{$\begin{array}{l}\text { Số trâm hạch N1 } \\
\text { có di căn (vi trí) }\end{array}$} \\
\hline & & 0 & 1 & 2 \\
\hline 1 & 30 & 30 & & 0 \\
\hline 2 & 6 & 1 & & \\
\hline 3 & 14 & 11 & & 1 \\
\hline & & 72 & & \\
\hline
\end{tabular}

3.3. So sánh kết quả chẩn đoán di căn hạch trước mổ bằng $\mathrm{CT}$ và $\mathrm{PET} / \mathrm{CT}$ với kết quả mô bệnh

Bảng 5. So sánh kết quả chẩn đoán di căn hạch bằng CT với mô bệnh học

\begin{tabular}{|c|c|c|c|c|}
\hline \multirow{2}{*}{\multicolumn{2}{|c|}{$\begin{array}{l}\text { Chẩn đoán di } \\
\text { căn hạch } \\
\text { bằng CT }\end{array}$}} & \multicolumn{2}{|c|}{$\begin{array}{l}\text { Kết quả mô } \\
\text { bệnh hạch }\end{array}$} & \multirow{2}{*}{$\begin{array}{c}\text { Se; Sp } \\
\text { PPV; NPV }\end{array}$} \\
\hline & & $\begin{array}{l}\text { Không } \\
\text { di căn }\end{array}$ & $\begin{array}{c}\text { Di } \\
\text { căn }\end{array}$ & \\
\hline \multirow{2}{*}{$\begin{array}{c}\text { Hach } \\
\text { N1 }\end{array}$} & $\begin{array}{l}\text { Không } \\
\text { di cănn }\end{array}$ & 62 & 3 & \multirow{2}{*}{$\begin{array}{l}50,0 \% ; 83,8 \% \\
20,0 \% ; 95,4 \%\end{array}$} \\
\hline & Di căn & 12 & 3 & \\
\hline \multirow{2}{*}{$\begin{array}{l}\text { Hach } \\
\text { N2 }\end{array}$} & $\begin{array}{l}\text { Không } \\
\text { di căn }\end{array}$ & 64 & 3 & \multirow{2}{*}{$\begin{array}{l}62,5 \% ; 86,1 \% \\
33,3 \% ; 95,4 \%\end{array}$} \\
\hline & Di căn & 8 & 5 & \\
\hline
\end{tabular}

Bảng 6. So sánh kết quả chân đoán di căn hạch bằng PET/CT với mô bệnh học

\begin{tabular}{|c|c|c|c|c|}
\hline $\begin{array}{c}\text { Chẩn đoán di } \\
\text { căn hach bằng } \\
\text { PET/CT } \\
\text { (n=49) }\end{array}$ & $\begin{array}{c}\text { Kết quả mồ } \\
\text { bệnh hạch }\end{array}$ & \multirow{2}{*}{$\begin{array}{c}\text { Se; Sp } \\
\text { Khônng } \\
\text { di căn }\end{array}$} & $\begin{array}{c}\text { Di } \\
\text { căn }\end{array}$ & \\
\hline \multirow{2}{*}{$\begin{array}{c}\text { Hạch } \\
\text { Nach }\end{array}$} & $\begin{array}{c}\text { Không di } \\
\text { căn }\end{array}$ & 42 & 1 & $97,7 \% ; 83,3 \%$ \\
\cline { 2 - 4 } & Di căn & 1 & 5 & $97,7 \% ; 83,3 \%$ \\
\hline \multirow{2}{*}{$\begin{array}{c}\text { Hachn } \\
\text { N2 }\end{array}$} & $\begin{array}{c}\text { Không di } \\
\text { căn }\end{array}$ & 39 & 2 & $97,5 \% ; 83,3 \%$ \\
\cline { 2 - 4 } & Di căn & 2 & 6 & $97,5 \% ; 83,3 \%$ \\
\hline
\end{tabular}




\section{BÀN LUẬN}

\section{1. Đăc điểm đối tượng nghiên cưu}

- Tuổi: Theo Nguyễn Khắc Kiểm (2016): tuổi trung bình của bệnh nhân UTPKTBN được điều trị phẫu thuật là $56,2 \pm 8,59$, độ tuổi từ 51 đến 70 chiếm chủ yếu $(75,9 \%)$, nhóm tuổi từ 51 đến 60 chiếm tỷ lệ cao nhất $(48,6 \%)$ [6].

- Giới: Hầu hết các báo cáo cho thấy, nam giới mắc UTPKTBN cao hơn nữ giới. Theo Cù Xuân Thanh (2002), tỷ lệ nam/nữ là 9/1; Nguyễn Khắc Kiểm (2016) là 3,9/1 [6].

Như vậy, kết quả của chúng tôi là tương tự các tác giả trên.

- Kích thước u và giai đoạn TNM

Trong giai đoạn đâuu ứng dụng PTNSLN điều trị UTPKTBN, chỉ định thường giới hạn ở những BN có u kích thước nhỏ (dưới $5 \mathrm{~cm}$ ), giai đoạn TNM sớm. Begum $S$ và cs (2014), Scott W. J và cS (2010) phẫu thuật với $100 \%$ giai đoạn I và II [4]. Tuy vậy, nhờ sự thuần thục về kỹ thuật, chỉ định của kỹ thuật ngày càng được mở rộng. Mc Kennna (2006), tiến hành PTNSLLN điêu trị cho BN UTPKTBN giai đoạn đến IIIA. Tác giả phẫu thuật cho 1015 BN, giai đoạn I chiếm 87,9\%, IIA tỷ lệ 1,3\%, IIB tỷ lệ $0,9 \%$ và IIIA tỷ lệ 2,2\% [3].

Chúng tôi thực hiện PTNSLN điều trị cho những $B N$ có kích thước $u$ lớn nhất đến $6,5 \mathrm{~cm}$, $u$ chưa xâm lấn thành ngực (giai đoạn T1-2b). Xếp giai đoạn TNM lâm sàng từ I đến IIIA, trong đó giai đoạn IIIA là $10 \%$.

4.2. Về kết quả vét hạch bằng phẫu thuật nội soi. Kết quả lấy mẫu hạch hay vét hạch thường dựa trên số lượng hạch lấy được hoặc số vị trí vét được hạch (theo sơ đồ hạch) trong phẫu thuật. Vét hạch trên nhóm BN UTP không TBN giai đoạn trước mổ từ I đến III, tác giả Lee P. C và cs (2013) cho biết, số trạm hạch N1 được vét là $1,4 \pm 0,5$, hạch N2 là $1,9 \pm 0,7$ [2]. Theo Scott W. J và cs (2010), tổng số trạm hạch được vét trong mổ là 4,3 [4].

Chúng tôi, đã thực hiện vét hạch được trung bình $1,8 \pm 0,8$ trạm hạch $\mathrm{N} 1$ và $1,8 \pm 0,7$ trạm hạch N2 bằng PTNS. Như vậy số vị trí vét hạch của chúng tôi tương đương các tác giả trên.

4.3. Về kết quả chẩn đoán di căn hạch trước mổ

- Chẩn đoán di căn hạch bằng CLVT lồng ngực

Tổng kết của Amstrong P (2001) cho thấy, CLVT lồng ngực có độ nhạy từ $60 \%$ đến $65 \%$ và độ đặc hiệu từ $60 \%$ đến $70 \%$ trong chẩn đoán di căn hạch [1]. Yang Xia và cs (2015) cũng đưa ra số liệu tướng tự, với độ nhạy đạt $57 \%$, độ đặc hiệu $82 \%$, giá trị tiên đoán dương $56 \%$ và giá trị tiên đoán âm là $83 \%$ [7].
Kết quả nghiên cứu của chúng tôi, với các giá trị tương tự trong chẩn đoán di căn hạch N1 lần lượt là: $50,0 \%, 83,8 \%, 20,0 \%$ và $95,4 \%$; N2 lân lượt là $62,5 \%, 86,1 \%, 33,3 \%$ và $95,4 \%$.

- Chẩn đoán di căn hach bằng PET/CT

Theo Yang Xia và cs (2015), PET/CT có độ nhạy $68 \%$ và độ đặc hiệu khoảng $80 \%$ trong chẩn đoán di căn hạch [7]. Nhìn chung, độ nhạy và độ đặc hiệu của $\mathrm{PET} / \mathrm{CT}$ trong chẩn đoán hạch rốn phổi và trung thất vào khoảng $83 \%$ (77 - $87 \%)$ và $92 \%(89-95 \%)$.

Nghiên cứu của chúng tôi cho kết quả tương tự, thể hiên ở bảng 6 . Kết quả này một lần nữa khẳng định, $\mathrm{PET} / \mathrm{CT}$ là xét nghiệm rất có giá trị trong chẩn đoán di căn hạch. Chỉ định PET/CT để xác định giai đoạn trước mổ là cần thiết và cần được thực hiện thường quy.

\section{KẾT LUẬN}

Vét hạch bằng phẫu thuật nội soi điều trị UTPKTBN khả thi, hiệu quả. Áp dụng PET/CT trong chẩn đoán di căn hạch trước mổ đạt hiệu quả cao.

\section{TÀI LIỆU THAM KHẢO}

1. Armstrong P., Congleton J., Fountain S. W. et al. (2001), "Guidelines on the selection of patients with lung cancer for surgery", Thorax, 56 , $89-108$.

2. Lee P. C., Nasar A., Port J. L., et al. (2013), "Long - Term Survival After Lobectomy for Non Small Cell Lung Cancer by Video - Assisted Thoracic Surgery Versus Thoracotomy", Ann Thorac Surg, 96, 951 - 961.

3. McKenna R. J., Houck W., Fuller C. B. (2006), "Video - Assisted Thoracic Surgery Lobectomy: Experience With 1,100 Cases", Ann Thorac Surg, $81,421-426$.

4. Scott W. J., Matteotti R. S., Egleston B. L., et al. (2010), "A comparison of perioperative outcomes of Video - Assisted Thoracic Surgical (VATS) Lobectomy with open thoracotomy and lobectomy: Results of an analysis using propensity score based weighting", Annals of Surgical Innovation and Research, 4(1), 1 - 6 .

5. Darling D. E., Allen M. S., Decker P. A., et al. (2011), "Randomized trial of mediastinal lymph node sampling versus complete lymphadenectomy during pulmonary resection in the patient with NO or N1 (less than hilar) non - small cell carcinoma: Results of the American College of Surgery Oncology Group Z0030 Trial", J Thorac Cardiovasc Surg, 141(3) $662-670$.

6. Kiếm Nguyến Khắc (2016), Nghiên cứu nạo vét hach theo bản đồ trong phẩu thuất điêu trị ung thư phổi không tế bào nhỏ giai đoạan I - II - IIIA, Đại học Y Hà nội, Hà nội.

7. Yàng Xia., Bín Zhang., Hao Zhang., et al. (2015), "Evaluation of lymph node metastasis in lung cancer: who is the chief justice?", Journal of Thoracic Disease, 7(S4), S231 - S237. 